人保田彰

南川まよか

小松 正规

神你川県立がんセンター 便頙科

\section{化学放射線同時併用療法によって喉頭温存を 目指した頭頸部扁平上皮癌の検討}

化学放的線同時併用抾によって喉㿟温存を日指した頭顠部扁平上皮病症例を

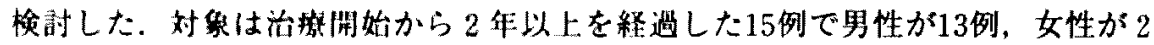

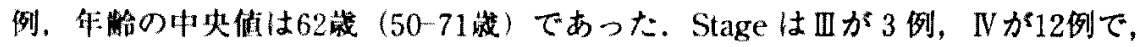

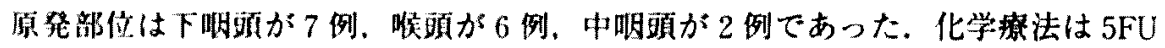
の $1000 \mathrm{mg} / \mathrm{m}^{2}$ を+1䦌の持㿠点谪とCis-platinum $の 60 \mathrm{mg} / \mathrm{m}^{2}$ 点滴で 2 コー

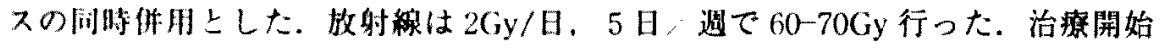
後26日から35日までの放射楾休止期間を設定した。放射線の中央值は66Gyであ

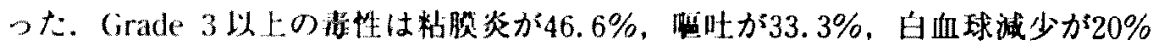

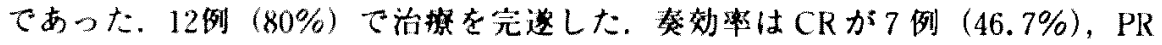
が8例 (53.3\%) てあった。生存畍間の中央值は27.2月（5.6-33.9月）， Progression free survival(PFS) の中央值は26.5月（5.6-33.9月）であった。 2

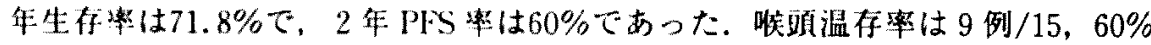
上良好な成緹であった。再発形式は局所 㖶部リンパ節の 5 例，遠隔転移の 1 例

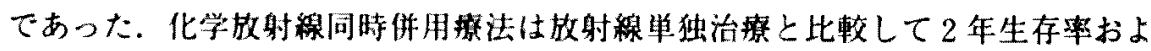

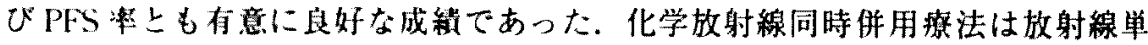
独治撩と比较し喉頚温存慗とともに，生存率も向上し，喉頭全摘に上るQOLの 低下を回避することが示惨された。

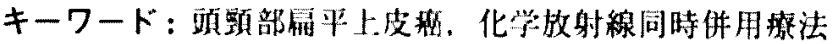 (is-platinum(CDDP)，5-Fluorouracil (5-FU)，滕器温存}

\section{はじめに}

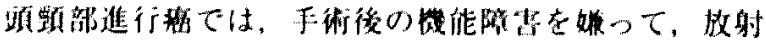

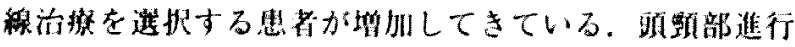

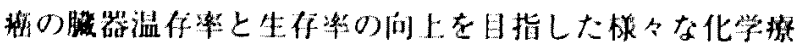

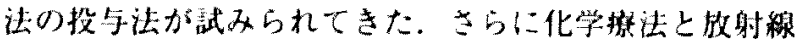

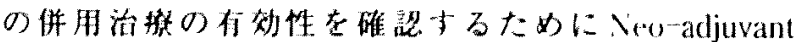
chemotherapy (NAC) $)^{n-\cdots s}$, concurrent chemoradiother-

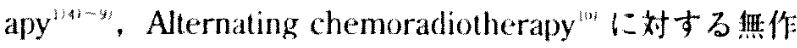
為比較試験が行われてきた。

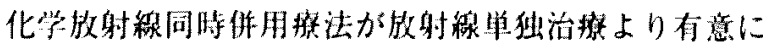

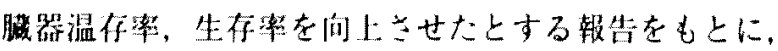

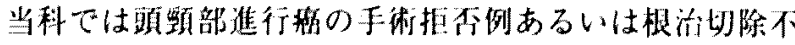
能な拝例に1999年6月より (is platinum (CDDP) と

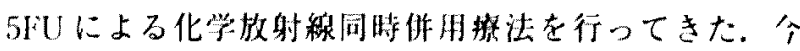
回は化学放射線同時併用撩法によって㬋㖽温仔を日指し

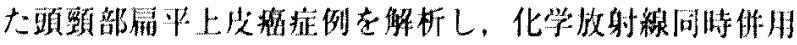

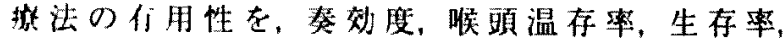
Progression free survival(PFS) 辈から模討した。

\section{対哀および方法}

\section{1. 对象症例}

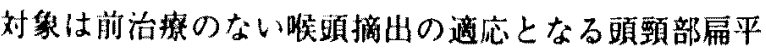
上皮潘の手術拒否例とした，当科の喉稹摘出の適応基準 は slage III, IV O進行癌で喉頭，下咽頍はT3以上ある いはT2以下でも正中を越える病変，中咽頭はT2以上

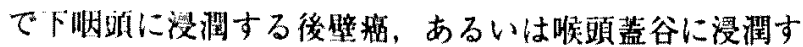

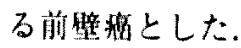

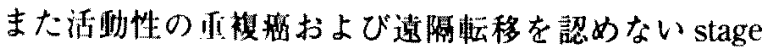
IIIおよびNで, 1999年3月31日から2000年10月20日ま で，治撩開始から 2 年以上を経過した症例とした。治療 阙始から 2 年以上の症例を対象とした理由は 2 年以降の 再発が少なく2年の粗生存事とPFS 率を検討すれば， 
それ以降の遠隔成緹を予測できることにある。ささらに测

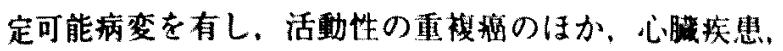

膅尿病など治撩の支障上なる合併症のない症例で，血液 検查は白血球が $3900 / \mathrm{mm}^{3}$ 以上, 血色素が $10 \mathrm{~g} / \mathrm{dl}$ 以上. 血小板が10万/ $/ \mathrm{mm}^{3}$ 以上，生化学㭘查は尿素空素が $20 \mathrm{mg} / \mathrm{dl}$ 以下．クレアチニンが $1.2 \mathrm{mg} / \mathrm{dl}$ 以下．GOT. GPTが施設正常值の２倍以内上规定した. performance status(PS)は1 以下で年硧は75藏以下を対象とした。

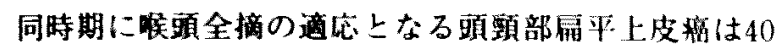

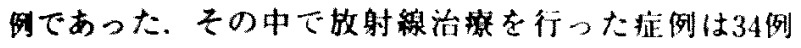
で、本撩法の道心基㴖を满たさない9例を除いた25例に

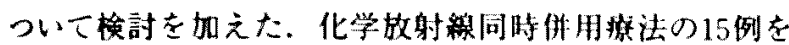

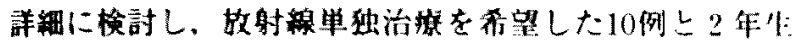
存事およびPFS蚌を比较した。

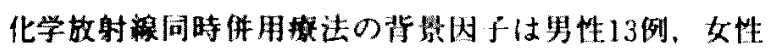

2 例，年粭は50藏から71葴で，中央值は62墄であった。 Stage は田が 3 例，Nが12例で，T3以上が10例，N2 以 トが11例と進行例が多数を占めていた. PSはすべて0 であった，原発部位は下咽頭が 7 例，喉頭が 6 例，中咽 頭が 2 例であった．化学放射線同時併用と放射線単独療 法の対象症例は表 1 に示した. CDDP と5FUの NAC を 化学放射線同時併用は 2 例に放射線単独療法は 3 例に行 った. Nedaplatin と UFT $の$ adjuvant chemotherapy は化 学放射線同時併用撩法では11例に，放射線単独療法は 6 例に行ったＮACは手術と放射線治療の選択に迷った

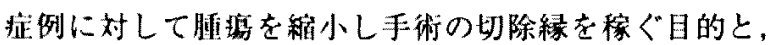
治稳方法を照者が自己退択する時間的猶予をつくるため に行い, adjuvant chemotherapy は局所再発上遠隔転移 の抑制を川的に行うとの説明にそれぞれ同意した症例に 行た。

表 1 症例一䜿

化学故射的同時併用

\begin{tabular}{|c|c|c|c|c|c|c|c|c|c|}
\hline & 性 & 年粭 & 原発 & 亜部位 & 病期 & $\mathrm{T}$ & $N$ & 奏效度 & 転㷌（M） \\
\hline 1 & $M$ & 50 & 下朋到 & PS & 3 & 3 & 1 & $\mathrm{CR}$ & NED $(33.7)$ \\
\hline 2 & $M$ & 52 & 卜㖼䁰 & PS & 4 & 4 & 0 & $\mathrm{CR}$ & NED (31.2) \\
\hline 3 & $M$ & $\pi$ & 下㑼副 & PS & 4 & 2 & $2 b$ & PR & 肺転移 \\
\hline 4 & $M$ & 66 & F唨颔 & PS & 1 & 2 & $2 \mathrm{~b}$ & $\mathrm{PR}$ & リンパ節再発 \\
\hline 5 & $M$ & 64 & 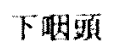 & $\mathrm{PC}$ & 4 & 4 & $2 \mathrm{~b}$ & $\mathrm{CR}$ & 胃穿孔 \\
\hline 6 & $M$ & $5 \pi$ & 下喟㽬 & PC & 4 & 1 & $2 b$ & $\mathrm{CR}$ & NED $(32.6)$ \\
\hline$i$ & $M$ & 60 & 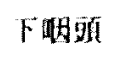 & PS & 4 & 3 & $2 b$ & PR & 局所再発 \\
\hline 8 & 11 & 62 & 喉㩆 & $G$ & 3 & 3 & 0 & $\mathrm{CR}$ & 局所再発 \\
\hline 9 & $M$ & 68 & 唯端 & c; & 3 & 3 & 1 & PR & $\mathrm{NED}$ \\
\hline 10 & $F$ & 70 & 崔酘 & G & 4 & 4 & $21)$ & PR & NED (27.8) \\
\hline 11 & $M$ & 58 & 喉端 & $s i$ & 4 & 2 & 20 & PR & NED $(25.3)$ \\
\hline 12 & $M$ & 56 & 喉颀 & $G$ & 4 & 3 & $2 b$ & PR & リンパ節再発 \\
\hline 13 & $\mathrm{~F}$ & 59 & 喉䫓 & (; & 4 & 3 & $2 b$ & PR & NED (26.5) \\
\hline 14 & $M$ & 66 & 中㽞形 & $A W$ & 4 & 2 & 2b & $\mathrm{CR}$ & NED (33.9) \\
\hline 15 & $M$ & 62 & 中啲到 & $\mathrm{PW}$ & 4 & 3 & $2 b$ & $\mathrm{CR}$ & NED $(31.7)$ \\
\hline \multicolumn{10}{|c|}{ 故射線単虻 } \\
\hline 1 & $M$ & 68 & 下咽㑔 & PS & 3 & 3 & 0 & $\mathrm{CR}$ & NED $(35.7)$ \\
\hline 2 & $M$ & 66 & 下明酸 & $\mathrm{PW}$ & 4 & 4 & $2 b$ & PR & 局所再発 \\
\hline 3 & $M$ & 68 & 下咽潩 & PS & 4 & 4 & 0 & $\mathrm{PR}$ & 局所再発 \\
\hline 4 & $M$ & 65 & 下㗅嘼 & PS & 4 & 3 & $2 b$ & $\mathrm{NC}$ & 局所再発 \\
\hline 5 & $M$ & 72 & 下喵嘼 & PS & 4 & 3 & 20 & $\mathrm{CR}$ & 局所再発 \\
\hline 6 & M & 69 & 下咽歌 & $\mathrm{PC}$ & 4 & 4 & $2 b$ & PR & 局所再発 \\
\hline 7 & $M$ & 60 & 喉耐 & $G$ & 3 & 2 & 1 & PR & NED $\quad(43.0)$ \\
\hline 8 & $F$ & 73 & 中咽頭 & PW & 3 & 3 & 1 & PR & 局所再発 \\
\hline 9 & $\mathrm{M}$ & 56 & 中咐䫓 & $\mathrm{AW}$ & 4 & 4 & $2 \mathrm{~b}$ & CR & 緥附リンバ節 \\
\hline 10 & M & 68 & 中咽湢 & PW & 4 & 3 & $2 \mathrm{a}$ & $\mathrm{PR}$ & リンバ節再発 \\
\hline
\end{tabular}

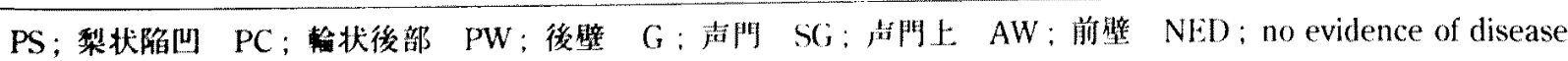




\section{2. 治丵力法}

放射線は1日2Gyを邀に5日の conventionalな方法

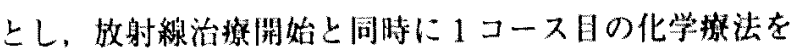
併用し，40Gy 照射路了時に1週间の休みを钤定した。 放射線治撩再開と同時に2 た。照射れは60Gyから70Gyで，日標稳量は66Gyに 設定した，化学竸法は $5 \mathrm{FU}$ を $1000 \mathrm{mg} / \mathrm{m}^{2}$ の 4 日間の持 続点滴とCDDP を $60 \mathrm{mg} / \mathrm{m}^{2} て ゙ 4$ 日目に㸃谪投与した。

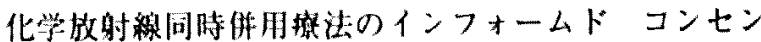

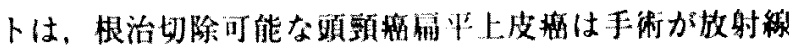
より根治性が鬲い上されているとの䫓明に対して，牧射

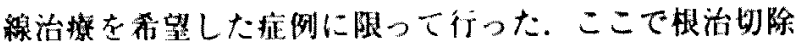

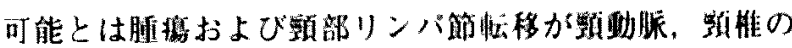

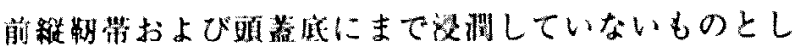

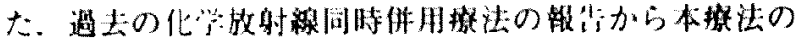

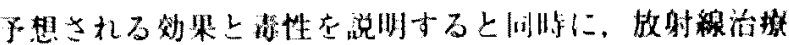

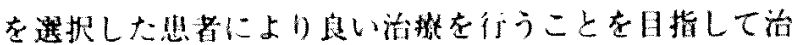

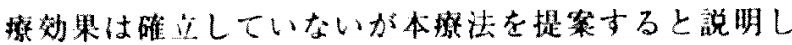

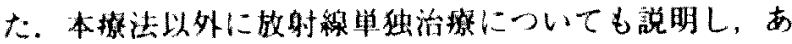
くまても治撩の決定は自発的な患者の意思によるもので あるこ上を確認した上で治掠の同意を得た。

3. 抗腫境效果判定上鉢性の部洒

抗脽境效果判定は治撩䅂了1力月後に施行した。画像

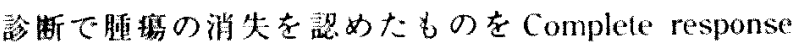
( (R：者知)，50\%以上の樎小をPartial response (PR: 有钬)，50\%末渶の縮小扰上び25\%末満の增大をNo

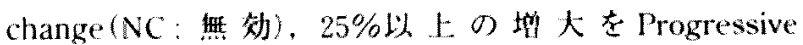
disease(PD：增大) と判完した。2力所以上の部位で

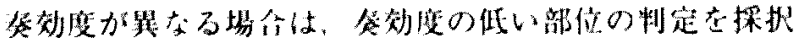
した。

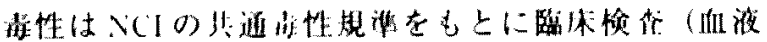

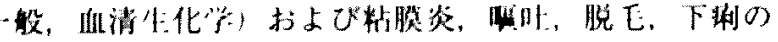
自他觉所見で詁洒しだ

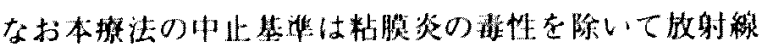

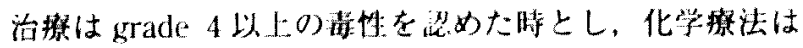
粘膜炎と哩时を除くgrade 3 以上の清性あるいは2コー

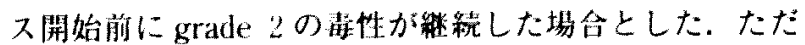

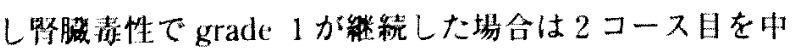
此した。

放射楾の中央檤は66Gy $(60-70 \mathrm{~Gy})$ で，12例，80\%

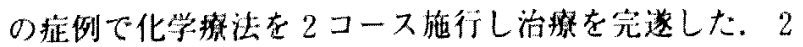
コース目を中止した3例の内於は grade 2 の白血球減少

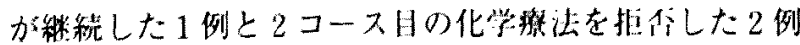
であった。

4. 生存期間と生存率

生仔期间は治療開始から最終徽察日までと規定した。
生存率は Kaplan-Meier 法で計算し, 有意差检定は Wilcoxon 法で行った，全例の予後を追跡した.

\section{結果}

1. 伤液谋性と四腸请性

Grade 3 以上の楼性は，血淮慗性が白血球隇少の 3 例 $(20 \%)$ と軽度たったのに対し，粘膜炎は 7 例 (46.6\%)

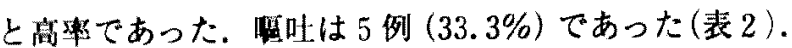

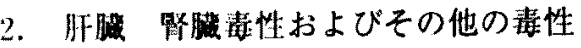

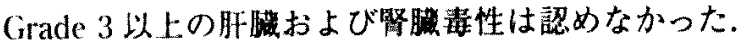

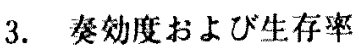

治效果は $\mathrm{CR}$ が 7 例 $(46.5 \%), \mathrm{PR}$ が 8 例 (53.3\%) と奏好独は100\%で良好であった（表 3）。生 存期間は5.6から33.9月，中央值は27.2月で, PFSの期 凩は5.6から33.9月，中央做は26.5月であった。 2 年生 作は71.8\%で，2年PFS舞は60\%といずれも良好な 成綝であった（图 1 )。

4. 侢発形式

本港法の中間成繒をまとめると再発のない症例は 9 例 で、再発なく生存している症例を眼器温存されたとする 上，60\%の症例の喉頍が温存された（表 4)，再発を認 めた症例は 6 例でその内訳は，局所再発が 3 例，顠部り

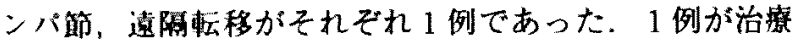
終了後の NSAID の内服による圈穿孔で死亡した。死亡 時点には再発を琶奻なったが，治療終了6力月以内で あったため原病死とした. Salvage 手術は局所再発した

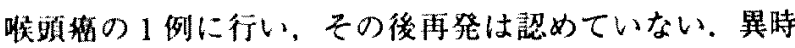

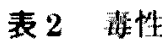

(化学放射線同時併用；15㓤)

\begin{tabular}{lrrrcc}
\hline \multicolumn{1}{c}{ Grade } & 0 & 1 & 2 & 3 & 4 \\
\hline 日血球減少 & 3 & 4 & 5 & $3(20)$ & 0 \\
血色素隇少 & 0 & 12 & 3 & 0 & 0 \\
粘膜炎 & 0 & 7 & 1 & $5(33.3)$ & $2(13.3)$ \\
咂吐 & 4 & 3 & 3 & $5(33.3)$ & 0 \\
体重娍少 & 6 & 4 & 5 & 0 & 0 \\
\hline
\end{tabular}

$(\%)$

表 3 替效度

(化学放射線同時伤用；15例)

\begin{tabular}{cc}
\hline & 症例数 $(\%)$ \\
\hline 者奻 $(\mathrm{CR})$ & $7(46.7)$ \\
有效 $(\mathrm{PR})$ & $8(53.3)$ \\
不変 $(\mathrm{NC})$ & 0 \\
墔大 $(\mathrm{PD})$ & 0 \\
\hline
\end{tabular}




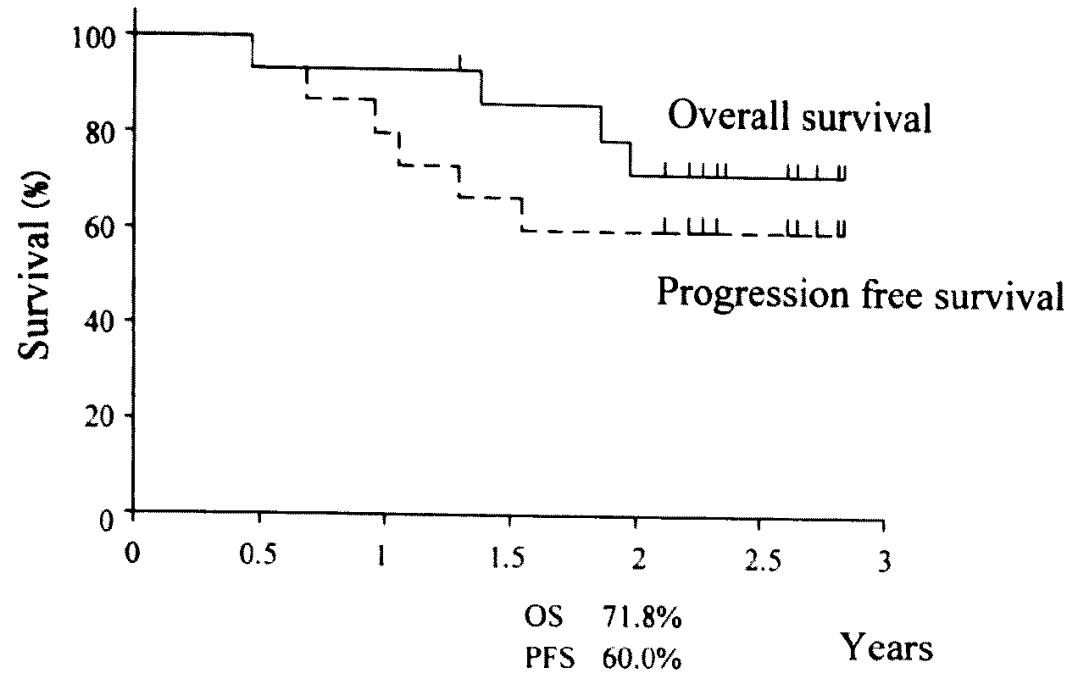

因 1 生存曲积

(化学放的線京時併用：15例)

表 4 中間䊅果

(化学故射间時併用；15例)

再発なし 9 例 $(60.0 \%)$

再発あり

局亲 6

到部りンバ節

遠䧀転移

他因死

salvage

生存

死亡

生存期間の平均

范用

5. 6-33.9

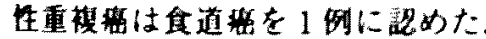

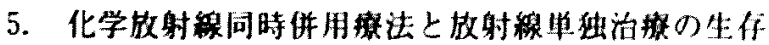
事

参考までにはは同時期に本撜法の対象となる拉例で放

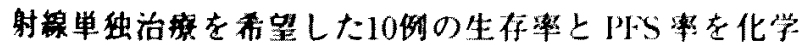

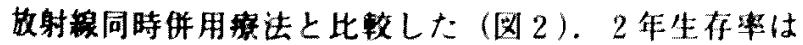
同時併用が $71.8 \%$ ，放射線単独が $20 \%$ で $(p=0.00618)$ ， 2 年 PFS 率も同時併用が $60 \%$ ，放射線单独が $20 \%$ と $(p=0.03687)$ ，いずれも化学放射線同時併用焪法が放 射線単独治獠より有意に良好であった。

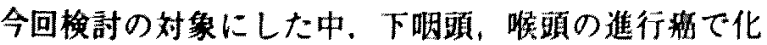
学䔔法と放射線の併用治療か腈器温存事および生存率を との程度向上するかを検討した数々の無作為比較陚䮖が

行われてきた。まず喉貊船に对する NAC (CDDP/5FU) の有用性が椮討されだ NACが奏効すれば放射線治療 を，無効なら喉頭摘出するNAC 群と，最初から喉頭摘 出と術後照射を行う手術群を比較したこころ，2年生存 事は両群とも68\%と同等だが、NAC 群では $39 \%$ で喉頭 が温存されただけではなく、邀隔転移も2\%と手術群の 6\%より有意に少なかったとしている．NACの奏効度

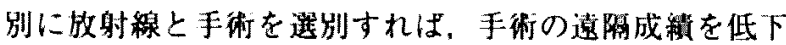
させることなく瞪器温存率を向上し，遠隔転移を抑制で きることが示された。

さらに喉䫂精で NAC（CDDP/5FU）が奏効すれば放 射線治繁を行い，無効の場合には喉頚摘出するNAC 群

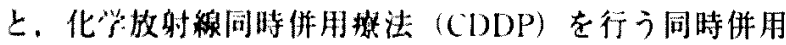

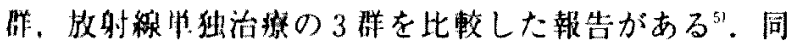

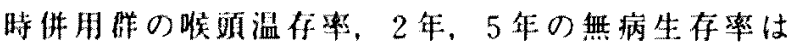
$84 \% ， 61 \% ， 36 \%$ と NAC 群 の72\%，52\%，38\%，放射 楾单䖽保の $67 \% ， 44 \% ， 27 \%$ より有意に良好であった２ 年， 5 年の遠隔転移华も同時併用群が $8 \% ， 12 \%$ と放射 棌単独群の $16 \%$ ，22\%より有意に低かった。ただ同時併 用群の 2 年, 5 年生存率は $74 \%, 54 \%$ で NAC 群の $76 \%$, $55 \%$ ，放射楾単独群の $75 \% ， 56 \%$ と各群に美がなかった

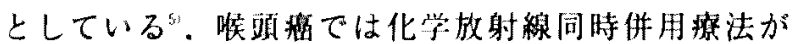
NAC 上り喉影温存率を向上させる叮能性がある。

中咽嘼精で化学放射線同時併用燃法 (Calboplatin/ 5FU）上放射線监独治撩の遠㓌成程を比較したところ同 時併用群の 3 年生存事， 3 年の Disease free survival 率 は $51 \% ， 42 \%$ で，いずれも放射線里独群の31\%，20\%よ り有意に良好であったと報告している゙。

下呐䫓梨状宿四の進行痽に対して NAC (CDDP/5FU) 


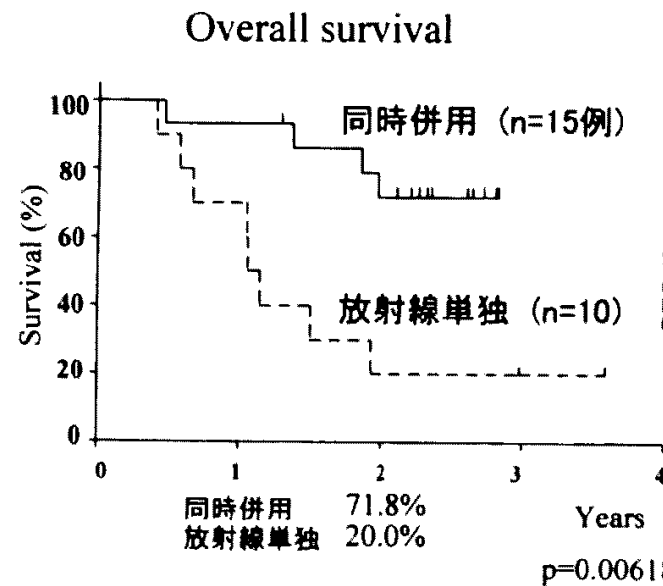

Progression free survival

因 2 化学放射線同時併用接法上放射線单独の生存曲線

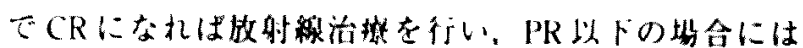

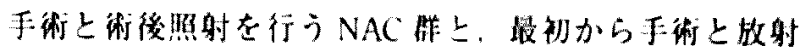

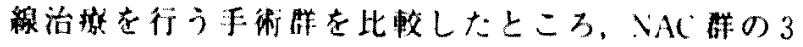
年，5年無病生存车は43\%，25\%で术群の32\%，27\% 上同等であったが、NAC 群の2 年，5年の㫿影温存整 は45\%，35\%であった。まNAC 群の平妁生存期間は

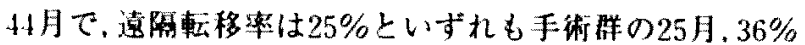
より有意に良好であったとしている゙。

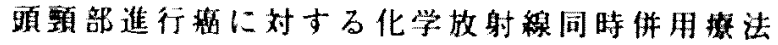

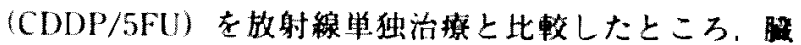
器温存きれた上での5年生存慗は原発部位別に差があり

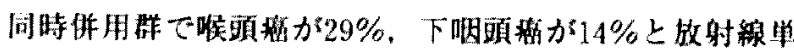

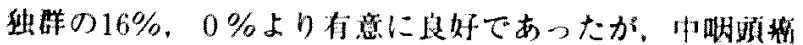

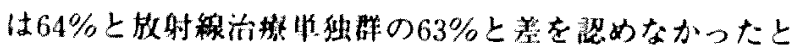

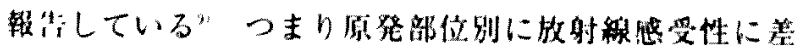

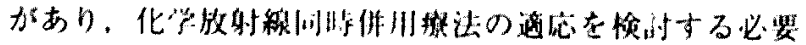
性があることを指摘している。

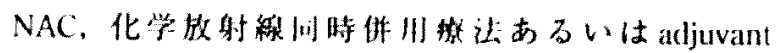
chemotherapy それぞれの们炏性について枱讨を加えた 無作為比粉武駼を meta analysis したところ，化学放射

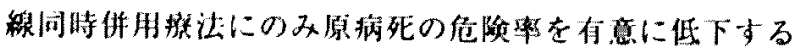

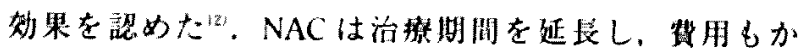
さむことから，手術の遙択肢がない場合は化学放射楾同 時併用揞法をすぐに開始することが推哲される。

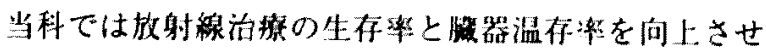
るために化学放射楾同時併用撞法（CDDP/5FU）を行

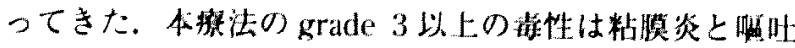

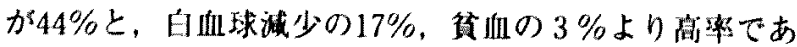

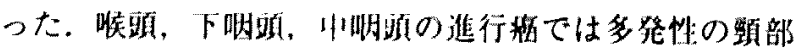
リンバ领転移を伴う症例が多く必然的に照射野が広くな り高度の粘脱炎が出現することに配算しなければならな

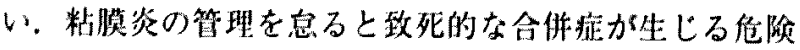

性があるが、feeding lubeの抑入あるいは中心静脈栄着

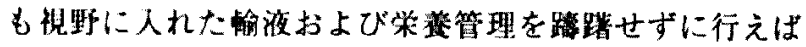
十分对処叮能な符用内であっだ

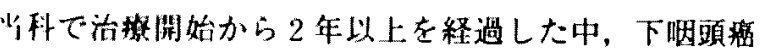

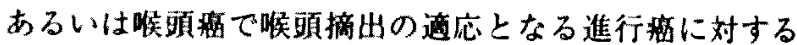
化学放射楾同時併用㙩法 (CDDP/5FU) の中間成稹

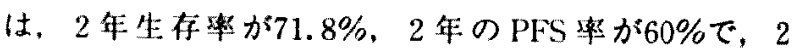

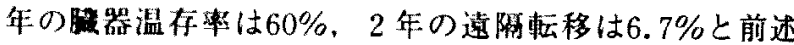
した過去の報告上比较しても同等かそれ以上で遜色のな い結果が得ら扎た。

当科の逍去の下咽聽癌に対する放射線治療成績は 5 年 生存が stage III で80\%，Nが24.9\%で, stage III とIV をあわせた脿器温存率は23.7\%であっだ、また今回化

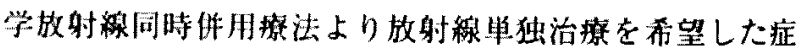
例の 2 作生你率は20\%，2年のPFS率は20\%と同時併 用と比較して有意に不良であったことから，化学放射線

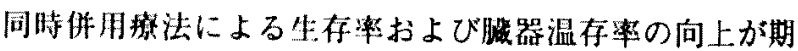
待される。

化学放射線闹時併用撞法後に行った手術の摘出病理標 本の㛟期から，垔部リンパ節転移で化学放射線同時併用

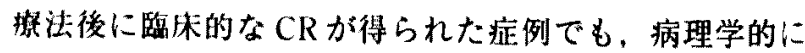

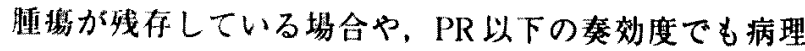
学的にCRの埸合があることが指摘された|516!．放射線 による炎症や浮䐺が残存するため，化学放射線同時併用

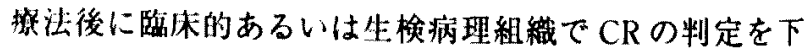
すのは蜼しい，そこで治猝後の西像診断が CRでも願部 リンパ節枟移が進行していた症例，あるいは腫瘍の残存 が疑わ机る症例に根治性を问上するために手術が追加さ れることがある。本舴法は手術拒否例を对象としたため

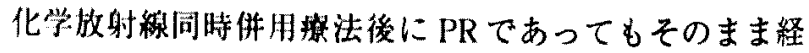
過钼察した症例が多い。（その結果臨床的にPRの 8 例中

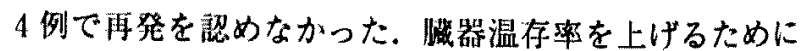


はPR 症例の中から、腫痛が残存している症例を見つけ 出す方法を確立する必要がある。

今後も化学故射線同時併用撩法を行った症例を追跡 し、晩期の毒性拉よび長期予後を明らかに方る必要があ 万.

$$
\text { まとめ }
$$

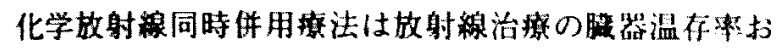

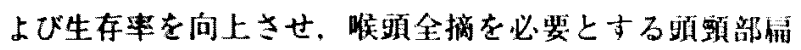
平上皮舟の手述を回避しQOL を維持する可能性が少さ れた。

\section{考支献}

1) Petrovich Z. Block J. Kuisk H, Mackintosh R. Cascialo D. et al: A randomized comparison of radiotherapy with a radiotherapy-chemotheray combination in stage IN carcinoma of the head and neck. Cancer 1981: 17 2259-2264.

2) Wolf GT. Hong WK. Fisher SC. Urba S. Fisher SR. et al Induction chemotherapy plus radiation compared with surgery plus radiation in patients with advanced laryngeal cancer. I Engl J Mad 1991: 324: 1685-1690.

3) Letebvre J-H. Chevalier D, Luboinski B. Kirkpatrick A. Collette $L$ et al for the FORTC head and neck cancer cooperative group: Larynx preservation in pyriform sinus cancer: preliminary results of a luropean organization for revearch and treatment of cancer phase III trial. J Natl Cancer Int 1945: sit 890-xy9.

4) Taylor SG. Murhy AK. Yannetzel JM, Colin P. Dray M, et al: Randomized comparison of neoadjuvant cisplatin and fluorouracil infusion followed by radiation viruls concomitant treatment in advanced head and neck cancer. J Clin Oncol 1994; 12: 385-395.

5) Farastiere AA, Forastiere H. Maor M. Pajak TF, Wrber $R$. et al: Concurrent chemotherapy and radiotherapy for organ preservation in advanced laryngeal cancer. N Engl J Med 2003: $349: 2091-2099$.

6) Wendt TG, Alfonsi M, Bardet E, Sire C, Germain $\mathrm{T}, \mathrm{dt}$ al: Simultaneous radiochemotherapy versus radiotherapy alone in advanced head and neck cancer: a randomized multicenter tudy. J Clin Oncol 1998; 16:1318 1324.

7) Al-Sarraf M, LeBlanc M. Giri PGS, Fu KK, Cooper J, et al: Chemoradiation versus radiationtherapy in patients with advanced nasopharyngeal cancer: phase III ran- domized intergroup study 0099. J Clin Oncol 1998: 16: 1310-1317.

8) Calais G, Alfonsi M, Bardet E. Sire C, T.Germain, et al: Randomized trial of radiation therapy versus concomitant chemotherapy and radiation therapy for advanced-stage oropharynx carcinoma. J Clin Oncol 1999; 24: 20812086 .

9) Adelstein 1)J, Lavertu P. Saxon JP. Seic M, Wood BG, et al: Mature results of a phase III randomized trial comparing concurrent chemoradiotherapy with radiation therapy alone in patients with stage III and IV squamous cell carcinoma of the head and neck. Cancer $2000 ; 88$ : $876-883$

10) Merlano M. Benasso M, Corvo R, Rosso R, Vitale V, et al: Five year update of a randomized trial of alternating radiotherapy and chemotherapy compared with radiotherapy alone in treatment of unresectable squamous cell circinoma of the head and neck. I Natl Cancer Inst $1996: 88,583-589$.

11) FIll 正德: National Cancer Institute-Common Toxicity Criteria (NCI CTC Version 2.0, Jan. 30, 1998) 一 日本望

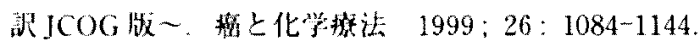

12) Pignon JP, Bourhis J, Domenge C, Designe L, MACHNC Collaborative Group, et al: Chemotherapy added to locoregional treatment for head and neck squamous-cell carcinoma: three meta analyses of updated individual data. Lancel 2000; 355:949-955.

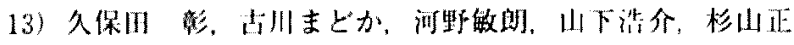

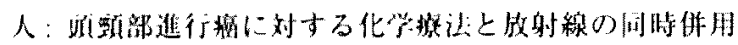
斑泣: 4 \% 2002:48:7-12.

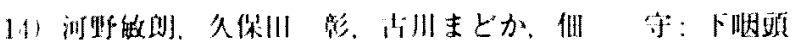

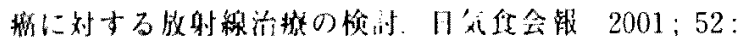
$325-330$.

15) M.Ham SA. Adelstein DJ, Rybicki LA. Lavertu P, Esclamado RM. et al: Who merits a neck dissection after definitive chemoradiotherapy for $\mathrm{N} 2-\mathrm{N} 3$ squamous cell head and neck cancer. Head Neck 2003; 25: 791-798.

16) Veldzquez RA, McGuff IS, Sycamore D, Miller FR: The role of computed tomographic scans in the management of the $n$-positive neck in head and neck squamous cell carcinoma after chemoradiotherapy. Arch Otolaryngol Head Neck Surg 20104; 130:74-77.

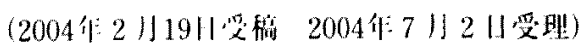

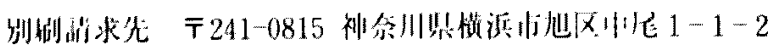

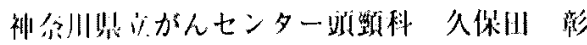


Concurrent Chemoradiotherapy for Head and Neck Squamous Cell Carcinoma Consisted with Indication of Total Laryngectomy

Akira Kubota, M.D., Madoka Furukawa and Masanori Komatsu, M.I).

Department of Head and Neck Surgery, Kanagawa Cancer Center, Yokohama

\begin{abstract}
Subjects were 15 patients - 13 men and 2 women - with squamous cell carcinoma of the head and neck, indicating total laryngectomy. Their median age was 62 years, ranging from 50 to 71 years. Three has stage III disease and 12 stage IV disease. The patients were treated with concurrent chemoradiotherapy and had been followed up for more than 2 years from the start of treatment. Primary siles were hypopharynx in 7, larynx in 6, or oropharynx in 2 . Treatment consisted of 5 Fluorouracil (5-FU) on cis platinum (CDDP). 5-FU was given at $1000 \mathrm{mg} / \mathrm{m}^{2}$ per day as continuous infusions during + days, and $60 \mathrm{mg} / \mathrm{m}$ of $\mathrm{CD}) \mathrm{l}^{\mathrm{x}}$ was given on day + beginning on day 1 and 35 of a concurrent chemoradiotherapy course. Radiation wis given in single daily fractions of 2 Gy and 5 fractions per week to a total dose of 60 to $70 \mathrm{~Gy}$. Radiation break was scheduled from day 26 to 35. The median total delivered dose of radiation was 66 (iv. Toxicitics included muconitis (grade 3, 33.3\%, grade 4. 13.3\%), vomiting (grade 3, 33.3\%). leukopenia (grade 3, 20\%). Twelve PT $(80 \%)$ received scheduled treatment. $x \cdot v \cdot n(46.7 \%)$ had clinical complete response and 8 (53.3\%) partial response. Median overall survival was 27.2 months $(5.6-33.9 \mathrm{~m})$ and progression-free survival was 26.5 months $(5.6-33.9 \mathrm{~m})$. The larynx was preserved and trec of disease in $60 \%$ of patients overall. Two-year overall survival (OS) was $71 . k^{4}$ and progression-free survival (PFS) rates was tirk. Failure patterns showed 5 with locoregional recurrence and 1 with distant metastasis. Concurrent chemoradiotherapy improved two-year OS and PFS compared to radiotherapy alone with a significant difference. Concurrent chemoradiotherapy is thus effective in preserving the larynx in a high percentage of patients and improving two year OS and PFS rates without compromising QOL.
\end{abstract}

Keywords: head and neck squamous cell cancer, concurrent chemoradiotherapy, (is platinum (CDDP) 5-Fluorouracil (5-FU), organ preservation 